\title{
KEBERTAHANAN SUBAK DI DESA KEDEWATAN UBUD, DI TENGAH-TENGAH ARUS PARIWISATA GLOBAL
}

\author{
I Ketut Setiawan \\ Fakultas Ilmu Budaya Universitas Udayana \\ Email: ketutsetiawan28@yahoo.co.id
}

\begin{abstract}
Abstrak
Pertanian sebagai kebudayaan sesungguhnya masih sangat berperan dalam mendukung pengembangan pariwisata, baik dari tata nilai, religiusitas, maupun lingkungannya. Lebih-lebih Ubud merupakan kawasan pariwisata yang sangat terkenal, baik di tingkat nasional maupun internasional. Ironisnya, sebagai daerah tujuan wisata populer, lahan pertanian rentan terhadap tekanan akibat pariwisata itu sendiri. Kenyataannya terjadi alih fungsi lahan pertanian menjadi lahan non pertanian yang difasilitasi oleh kebijakan pemerintah setempat. Selain itu, sumberdaya manusia yang semakin meningkat serta perkembangan industri yang terkait dengan pariwisata, semakin mendorong terjadinya alih fungsi lahan pertanian, khususnya sawah, menjadi lahan non pertanian untuk sarana dan prasarana pendukung pariwisata, seperti hotel, restoran, villa, toko cendramata, dan sebagainya. Penelitian ini dirancang sebagai penelitian yang menggunakan metode kualitatif dengan pendekatan cultural studies. Sebagai alat analisis dalam rangka mencari jawaban atas berbagai pertanyaan dalam penelitian ini digunakan dua teori, yaitu teori hegemoni dan teori praktik. Pengumpulan data dalam penelitian ini dilakukan dengan observasi, wawancara, dan studi dokumen.

Hasil penelitian menunjukkan sebagai berikut. Proses alih fungsi lahan persawahan di Desa Kedewatan, Ubud, terjadi melalui hegemoni dan negosiasi. Alih fungsi lahan persawahan tersebut merupakan bentuk hegemoni pengusaha (pemodal), penguasa (pemerintah) dan para petani itu sendiri, karena menganggap pariwisata memberi kesejahteraan lebih dibandingkan dengan bekerja sebagai petani. Ideologi yang bekerja di balik terjadinya alih fungsi lahan persawahan adalah ideologi ekonomi kapitalis dan gaya hidup. Alih fungsi lahan persawahan berdampak terhadap hilangnya infrastruktur sistem irigasi yang dikelola oleh organisasi subak, struktur sosial, kelembagaan, dan moral ekonomi petani.
\end{abstract}

Kata kunci: Subak, persawahan, pariwisata, petani, Kedewatan, Ubud.

\section{PENDAHULUAN}

Fenomena alih fungsi lahan persawahan menjadi lahan non pertanian akan berdampak luas terhadap tata budaya dan adat masyarakat Ubud. Fakta subak berada pada kawasan yang eksotik dengan panorama yang indah telah menggoda investor, dengan berbagai modus operandi untuk menguasai dan mendayagunakan lahan yang subur dan indah itu. Para investor berebut untuk mendapatkan area persawahan untuk menjadi sasaran akomodasi pariwisata. Menurut Dhyana (2009:36) area persawahan di Desa Kedewatan, Ubud sebagian telah terkapling dan harga tanah terus mengalami peningkatan. Hal itu menunjukkan ancaman terjadinya alih fungsi lahan di daerah Ubud yang dikenal sebagai daerah tujuan wisata unggulan di Kabupaten Gianyar, Bali.

Subak sebagai pranata sosial merupakan salah satu wujud budaya, baik ditinjau dari ide maupun gagasan yang dituangkan dalam awigawig subak. Dengan kebersamaan, kegotongroyongan, dan konsep tri hita karana yang diwujudkan dalam hubungan harmonis dalam bentuk tiga dimensi, menyebabkan subak dianggap mampu berperan melestarikan lingkungan dan budaya. Di samping itu, serentetan upacara dalam konteks kegiatan ritual, baik dilihat dari wujud fisik berupa petak-petak persawahan, terasering, saluran irigasi, maupun tempat-tempat suci (pura subak) seperti Pura Masceti, Pura Bedugul, menyebabkan peran subak mampu menjaga keseimbangan lingkungan (Pitana, 2003:61; Wirata, 2016:4).

Sementara itu, nilai-nlai yang terkandung di dalam subak tidak hanya berfungsi mengatur air irigasi, tetapi juga mampu menarik perhatian para ahli untuk mengadakan penelitian. Subak merupakan asset budaya yang khas dalam masyarakat Bali. Keindahan petak-petak sawah, kegiatan para petani di sawah mulai dari membajak tanah sampai menunai hasil panen, serta aktivitas ritual yang unik, mampu menarik para wisatawan.

Alih fungsi lahan pertanian, khususnya sawah, untuk kepentingan sarana dan prasarana pariwisata di Ubud mempunyai konskuensi logis. 
Dalam hal ini budaya pertanian dengan sistem subak yang merupakan salah satu modal dasar pariwisata budaya semakin terdegradasi, termasuk para petani yang belum siap bersaing di dunia modern yang sangat kompetitif. Di sisi lain, pariwisata dengan leluasa mengeksploitasi lahan pertanian untuk kepentingannya sendiri.

Jika keadaan ini berlangsung terusmenerus tidak mustahil Ubud yang terkenal dengan daerah seni, alam pedesaan yang sejuk, tanah yang subur, akan berubah menjadi Ubud yang gersang dan kering. Ubud memiliki kebudayaan, kesenian, dan keindahan alam yang menarik perhatian para wisatawan. Pura sebagai tempat suci umat Hindu akan leteh tercemar oleh derasnya kapitalisme lewat pariwisata. Semangat bisnis merajalela dan spekulasi atas tanah mencapai dimensi yang luar biasa oleh para spekulan dan konglomerat, serta masalah ekologi lainnya seperti polusi air, udara, dan sampah.

Di sisi lain, Ubud mengembangkan pariwisata berbasis budaya, artinya budaya Bali pada dasarnya berbasis pertanian. Dalam hal ini, perkembangan pariwisata di Ubud telah menyedot sumberdaya pertanian, baik berupa lahan maupun sumberdaya manusia. Dengan demikian, perkembangan pariwisata pada akhirnya akan mempengaruhi budaya Bali. Akibatnya, alih fungsi lahan persawahan akan berpengaruh terhadap kemajuan sektor pariwisata. Sesungguhnya ancaman terhadap penyusutan lahan persawahan di Ubud juga merupakan ancaman terhadap sektor pariwisata. Ancaman terhadap keberlanjutan persawahan juga berarti ancaman terhadap berkelanjutan budaya Bali yang berbasis pertanian (Wirata, 2016:7).

Alih fungsi lahan persawahan sebagai akibat adanya perkembangan pariwisata menandakan ambivalensi dalam realitas sosial, yaitu terjadi alih fungsi kawasan persawahan yang tidak disadari oleh para petani di Desa Kedewatan, Ubud. Di pihak lain disadari bahwa pariwisata membawa ancaman terhadap keberlanjutan kehidupan pertanian yang sarat dengan budaya Bali. Akibatnya, identitas "kebalian" mereka secara kolektif semakin menipis di desa kelahiran sendiri, yang sesungguhnya memiliki akar kuat pada kultur dan nilai pertanian yang sudah melembaga dengan tradisi serta menyatu dengan budaya hidup sehari-hari. Sebagai akibat dari kecenderungan inilah maka terjadi apa yang disebut sebagai "universalisme budaya", yaitu wajah budaya dunia dipandang menuju ke satu arah. Arah yang dimaksud adalah homogenisasi budaya modernitas serta memudarnya magis dan tradisi lokal.

Pertanian sebagai mata pencaharian utama dalam kehidupan manusia, telah mengalami suatu proses perkembangan yang sangat panjang. Penemuan kepandaian bercocok tanam merupakan suatu peristiwa besar dalam proses perkembangan kebudayaan manusia, bahkan seringkali peristiwa itu disebut sebagai suatu "revolusi" dalam peradaban umat manusia (Gordon Childe, 1953:1415). Masa ini amat penting dalam sejarah perkembangan masyarakat, karena pada masa ini beberapa penemuan baru berupa penguasaan sumber-sumber alam bertambah cepat. Berbagai macam tumbuh-tumbuhan mulai dipelihara, lahan pertanian mulai dikembangkan, sehingga tercipta persawahan yang memberi hasil-hasil pertanian.

Padi merupakan tanaman pertanian kuno yang sampai sekarang menjadi tanaman utama bagi masyarakat agraris. Berdasarkan bukti-bukti arkeologi menunjukkan bahwa padi telah dibudidayakan oleh masyarakat petani sejak lama. Beberapa daerah yang diduga menjadi daerah asal tanaman padi adalah India bagian timur, Bangladesh Utara, Myanmar, Thailand, Vietnam, dan Cina bagian selatan (Ardika, 1991:76). Kebudayaan bercocok tanam padi dibawah oleh para migrant dari Asia Tenggara yang mendiami daerah sekitar Pulau Formosa. Selanjutnya, mereka berimigrasi ke selatan, yang akhirnya tinggal menetap di kepulauan nusantara, menularkan kebudayaannya dan hidup bercampur dengan penghuni lama (Bellwood, 1985:5).

Di Bali, sistem pertanian persawahan dikelola oleh suatu lembaga yang bernama subak. Subak merupakan organisasi petani yang berkaitan dengan pengelolaan air irigasi serta bersifat sosioagraris religius. Sistem subak yang sudah dikenal di Bali sejak ribuan tahun, telah terbukti mampu meningkatkan produktivitas pertanian, khususnya padi.

Sementara itu, kegiatan dalam organisasi subak tidak selalu berkaitan dengan pertanian tetapi juga mencakup interaksi sosial antar warga petani dan ritual keagamaan untuk keberhasilan dalam bertani. Sistem subak di Bali dianggap memiliki nilai-nilai universal yang sangat penting artinya, sehingga diakui oleh UNESCO sebagai warisan budaya dunia (World Cultural Heritage) pada tahun 2012. Dengan demikian, sudah selayaknya menjadi tanggung jawab warga Bali untuk menjaga kelestarian subak itu sendiri. 
Namun demikian, kenyataan menunjukkaan bahwa akhir-akhir ini timbul berbagai kekhawatiran tentang eksistensi organisasi subak, seiring semakin meningkatnya alih fungsi lahan pertanian akibat pengembangan sector pariwisata.

\section{METODE PENELITIN}

Penelitian ini dirancang sesuai dengan paradigma keilmuan kajian budaya, yang menaruh perhatian untuk meneliti berbagai kepentingan ideologi dan hegemoni dalam kaitannya dengan kekuasaan. Adapun metode yang digunakan adalah metode kualitatif yang sumbernya digali dari kepustakaan dan lapangan. Pengumpulan data dilakukan dengan observasi, wawancara dan studi dokumen. Pada tingkat analisis digunakan teknik analisis kualitatif dengan cara (1) reduksi data, (2) penyajian data, dan (3) penarikan simpulan.

\section{HASIL DAN PEMBAHASAN}

Keberadaan subak di Desa Kedewatan, Ubud tidak dapat dipisahkan dengan seluruh kegiatan pariwisata, karena sebagian anggota subak merupakan krama desa Ubud. Fenomena terhegemoninya petani oieh perusahaan adalah keberhasilan secara ideologi kapitalisme dalam usaha untuk terus menancapkan kekuasaannya dalam kehidupan petani. Jika dilihat daiam lintas sejarah, posisi petani menunjukkan identitas masyarakat petani telah terampas akibat kekalahan dalam kontestasi yang terjadi dalam masyarakat kolonial. Dalam posisi ini keterpinggiran masyarakat petani terdominasi oleh ruang dan waktu, karena eksistensi kekuasaan yang dominan, seperti pengusaha, pemerintah, dan kapitalis. Kapitalis sebagai pihak dominan memandang semua hal atau objek bisa dijadikan modal untuk mendapatkan keuntungan sebesar-besarnya. Di sisi lain, masyarakat sulit mendapatkan kehidupan yang layak akibat modernisasi zaman, yang mendorong setiap individu bersaing dan berkompetisi dalam memenuhi kebutuhan hidup. Salah satu diantaranya adalah kebutuhan tempat tinggal yang meningkat.

Adanya kebutuhan yang demikian banyak menjadi peluang yang besar bagi kaum kapitalis untuk menanamkan modalnya. Kuatnya modal materialisme membuat semua hal yang diinginkan menjadi mungkin terjadi, termasuk juga melakukan alih rungsi lahan pertanian. Kini kaum kapitalis mulai menyisir lahan-lahan produktif. Salah satu di antaranya adalah lahan pertanian sawah sebagaimana yang terjadi di wilayah subak di Desa Kedewatan, Ubud, Gianyar.

Kapitalis berkolaborasi dengan penguasa, yaitu memakai dalih pembangunan yang direstui oleh pemerintah untuk melanggengkan tindakannya. Oleh karena itu, aktivitasnya untuk menyukseskan pembangunan sebagai bagian dari program pembangunan menjadi legal. Pada hakikatnya, pembangunan sesungguhnya merupakan upaya untuk pemenuhan kebutuhan dasar manusia, baik secara individu maupun kelompok dengan cara-cara yang tidak menimbulkan kerusakan, baik terhadap kehidupan sosial maupun lingkungan alam. Namun, dalam hal ini pembangunan telah disalahgunakan menjadi faktor terjadinya alih fungsi lahan persawahan yang mengakibatkan marginalisasi sebagian petani di kawasan Ubud, Kabupaten Gianyar. Alih fungsi lahan persawahan menjadi sarana dan prasarana pariwisata berdampak kepada kondisi kehidupan petani, seperti kurangnya pendapaan, peran sosial, orientasi nilai budaya, strasifikasi sosial, kesempatan kerja, dan kesempatan berusaha. Kondisi seperti ini menempatkan masyarakat petani dalam posisi subalter, yaitu kelompokkelompok orang yang terpinggirkan atau termarginalkan.

Alih fungsi lahan persawahan terjadi tidak hanya akibat belum maksimalnya kebijakan pemerintah dalam membela kepentingan petani, tetapi juga akibat para petani mulai goyah dalam mempertahankan swadharmanya sebagai petani dan tergiur pekerjaan lain. Memang nasib petani di kawasan wisata Ubud kini kian terpuruk. Selain masih dianggap termarginalkan, permasalahan yang dihadapi petani semakin kompleks, sementara pemerintah daerah belum maksimal memberi perhatian tentang kesulitan yang dirasakan para petani. Pada hal, selain sektor pariwisata, pertanian juga masih tetap memegang peranan strategi menjaga stabilitas dan pemerataan perekonomian di Bali pada umumnya, dan Ubud pada khususnya. Sektor pertanian menjadi semakin suram sebagai akibat adanya alih fungsi lahan dan air irigasi semakin terbatas, karena sebagian diambil oleh PDAM dan kepentingan pariwisata, sehingga para petani di Desa Kedewatan, Ubud, semakin lemah. Generasi muda enggan menjadi petani (wawancara dengan Darmaputra, Pekaseh Subak Tegallalang tanggal 22 Juni 2017). Di samping itu, keengganan menjadi petani juga akibat dari tingginya harga benih, pupuk, biaya pengelolaan lahan seperti traktor, upah tanam, panen, ditambah lagi harga 
jual hasil panen tidak menentu, serta beban pajak yang dianggap masih memberatkan kehidupan petani.

Dengan kondisi seperti itu kiranya cukup beralasan bahwa generasi muda di Ubud tidak ada yang mau menjadi petani. Bahwa menjadi petani merupakan pekerjaan yang melelahkan dan tidak menjanjikan kehidupan masa depan yang lebih baik. Kondisi seperti ini tentunya berdampak pada upaya pelestarian sawah dan sistem subak sebagai masyarakat agraris.

Selain hal-hal di atas, pengaruh modernisasi juga berperan besar terhadap pola pikir masyarakat. Zaman modern membuat petani seakan-akan lupa diri dan tergiur dengan kenikmatan atau keasyikannya yang cenderung konsumtif sebagai gaya hidup budaya konsumerisme. Secara tidak langsung masyarakat petani dihegemoni dengan materi berupa barangbarang yang diproduksi oleh kaum kapitalis dengan tujuan agar masyarakat Ubud menjadi masyarakat konsumerisme. Gaya hidup instan, serba cepat, dan praktis merupakan ciri khas sikap manusia modern.

Kuatnya hegemoni kapitalisme dan gaya hidup modern juga berpengaruh terhadap pemilihan mata pencahanan hidup. Modernisme meletakkan pekerjaan petani sebagai pekerjaan kasar, tradisional, sehingga tidak layak dikerjakan oleh orang modern. Akibatnya, mata pencaharian penduduk kawasan Ubud yang pada mulanya mayoritas adalah petani, dewasa ini beralih ke sektor pariwisata, perdagangan, dan jasa, karena mereka mendapatkan penghasilan yang lebih besar.

\section{SIMPULAN DAN SARAN}

Sistem pengairan tradisional Bali yang dikenal dengan nama subak, sudah berakar sejak lama dalam dinamika sejarah budaya dan masyarakat Bali. Ekosistem subak memiliki otonomi di bidang irigasi di pedesaan yang dipandang memiliki nilai, keyakinan dan prilaku budaya yang sudah dilaksanakan secara turun temurun dari dahulu hingga sekarang. Dapat dimengerti bahwa subak dipandang sebagai sistem yang mengandung nilai kearifan lokal tidak hanya bagi masyarakat Ubud pada khususnya, tetapi juga bagi masyarakat Bali pada umumnya.

Namun demikian, dengan adanya globalisasi dan modernisasi yang berkaitan dengan pengembangan program pembangunan pemerintah di bidang pariwisata yang mulai marak sejak tahun 1980-an, tampak secara langsung dan tidak langsung berdampak pada munculnya pergeseran dalam tatanan kehidupan masyarakat, khususnya masyarakat petani di wilayah perdesaan. Akan tetapi, pengaruh negatif masih dapat diantisipasi berdasarkan implementasi kebijakan pemerintah daerah, pengusaha lokal, dan masyarakat petani subak, yang mulai sadar akan dampak yang ditimbulkan oleh dunia industri pariwisata.

Terungkap dari hasii kajian ini adalah perlunya pengedepanan ajaran tentang konsep dan filosofi Tri Hita Karana secara aktual dalam kehidupan masyarakat dan bersinergi dengan para pengusaha dan pihak pemerintah daerah. Ajaran Tri Hita Karana itu telah menjadi jiwa dari sistem persubakan di Ubud pada khususnya, dan di Bali pada umumnya. Untuk mengantisipasi dampak yang kurang menguntungkan terhadap ekosistem subak, pemerintah hendaknya perlu memberikan peran yang lebih besar kepada warga subak dalam mengatur distribusi air di wilayahnya. Diharapkan bahwa peran subak dapat dikembalikan secara proporsional dalam konteks pemeliharaan bendungan, saluran primer, saluran sekunder, terowongan, dan hal-hal yang terkait dengan keberlangsungan sistem subak.

\section{UCAPAN TERIMAKASIH}

Penulis mengucapkan terimakasih yang sebesar-besarnya kepada semua pihak yang telah membantu memberi informasi tentang keberadaan subak di Desa Kedewatan, Ubud, terutama Pekaseh I Wayan Gandra, I Nyoman Rana, dan I Wayan Suka, pegawai di Kantor Camat Ubud.

\section{DAFTAR PUSTAKA}

Ambler, J.S. 1991. Dinamika Irigasi Petani: Kerangka dan Prinsip-prinsip Kelembagaan dalam Irigasi di Indonesia. Jakarta: LP3ES.

"Antara Subak dan Bisnis Pariwisata", OZON, Volume: 3, Nomor: 7, April 2002.

Arwata, A.A. Ngurah Made. 1990, "Tantangan Subak dalam Upaya Pelestarian Budaya Padi di Bali", dalam Subak dan Kerta Masa: Kearifan Lokal Mendukung Pertanian Berkelanjutan. Yapadi (Yayasan Padi Indonesia) dan IRF (Indonesia Rice Foundation). 
"Bali Akan Kehilangan Segalanya Bila Sistem Subak Punah", Kompas, 28 Maret 2002.

Djapa Winaya, Putu. 1972. Organization of Water Association in Bali", dalam Majalah Ilmiah Universitas Udayana. Denpasar.

Koentjaraningrat. 1993. Kebudayaan, Mentalitas, dan Pembangunan. Jakarta. Gramedia Pustaka Utama.

Pitana, I Gede. 2003. Pengantar Ilmu Pariwisata. Yogyakarta: Andi of Sat.

Suyatna, Gde. 1982. Ciri-ciri Kedinamisasn Kelompok Sosial Tradisional di Bali, dan Peranannya dalam Pembangunan, disertasi pada IPB. Bogor.
Windia, W. 2002. Tranformasi Sistem Irigasi Subak yang Berlandaskan Tri Hita Karana, (disertasi yang tidak dipublikasikan), Universitas Gadjah Mada, Yogyakarta.

Windia, W. 2004. Harmoni Sektor Pertanian dan Sektor Pariwisata Menuju Bali Jagaditha, dalam Menuju Bali Jagaditha (ed : N. Dharma Putra). Denpasar. Penerbit Bali Post,

Wirata Gede. 2016. Alih Fungsi Lahan Persawahan di Denpasar Selatan (Disertasi). Denpasar: Program Studi Kajian Budaya Unud. 